\title{
Enhancing the secretion pathway maximizes the effects of mixed feeding strategy for glucose oxidase production in the methylotrophic yeast Pichia pastoris
}

\author{
Olufemi Emmanuel Bankefa ${ }^{1,2}$, Meiyu Wang ${ }^{1,2}$, Taicheng Zhu ${ }^{{ }^{*}}$ and Yin $\mathrm{Li}^{{ }^{*}}$
}

\begin{abstract}
Background: A mixed feeding strategy (co-feeding of complex carbon sources with methanol) has become a common practice for process development in Pichia pastoris to increase cell biomass and enzyme production levels. However, in some cases mixed feeding did not have a significant impact or even had a negative effect on specific enzyme productivity. We hypothesized that this may be due to a bottleneck in the protein secretion pathway caused by too strong protein expression as a result of mixed feeding operation.

Results: Using glucose oxidase (Gox) as a model protein, the individual and synergistic effects of co-feeding of sorbitol or yeast extract (YE) with methanol and Hac1 p overexpression on the secretory expression of Gox were investigated both in shake flasks and in a laboratory fermenter. The results showed that YE is superior to sorbitol in terms of stimulating protein expression and cell growth. Moreover, separate applications of the mixed feeding strategy and secretory pathway engineering only achieved limited success in enhancing Gox levels, while the combined use of the two strategies acted synergistically, leading to $297 \%$ increase of Gox production and the final enzyme titer reached 787.4 U/mL in GSgox-Pp on 1-L fermenter.
\end{abstract}

Conclusions: Co-feeding of YE combined with secretion pathway engineering significantly improved glucose oxidase secretion, which can be also applied to improve secretory expression of other foreign proteins in P. pastoris system.

Keywords: Glucose oxidase, Hac1 p, Mixed feeding, Pichia pastoris, Secretion pathway engineering

\section{Background}

The methylotrophic yeast Pichia pastoris is one of the most important eukaryotic systems for industrial protein production. It has been used to successfully express more than 1000 proteins, and in recent years it has been used in the production of value-added chemicals (Yang and Zhang 2018). The P. pastoris system has many advantages, especially when methanol is used as feedstock.

\footnotetext{
*Correspondence: zhutc@im.ac.cn; yli@im.ac.cn

${ }^{1}$ CAS Key Laboratory of Microbial Physiological and Metabolic

Engineering, State Key Laboratory of Microbial Resources, Institute of Microbiology, Chinese Academy of Sciences, No. 1 West Beichen Road Chaoyang District, Beijing 100101, China

Full list of author information is available at the end of the article
}

These include facile high-density fermentation, cheap medium due to the low price of methanol, resistance to contamination, and the extremely strong AOX1 promoter for protein expression.

However, due to methanol's toxic nature, its concentration must be strictly controlled during the fermentation process (usually maintained below $5 \mathrm{~g} / \mathrm{L}$ ) (Cos et al. 2006; Looser et al. 2015), which greatly limits biomass accumulation and enzyme productivity. To address this challenge, mixed feeding strategies have become a common practice for process development (Cos et al. 2006), whereby methanol is co-fed with ancillary carbon sources, especially those that generally do not repress the AOX1 promoter, such as sorbitol, mannitol (Gu et al. 
2015), or lactate (Xie et al. 2005). Co-feeding of these carbon sources has proved to be a straightforward strategy to increase the supply of energy and carbon precursors for the synthesis of both biomass and target proteins.

Nevertheless, the effects of mixed feeding on process performance vary from study to study. For instance, in some cases, co-feeding of sorbitol led to increase of both cell growth and specific enzyme productivity, especially in recombinant strains with the $\mathrm{Mut}^{\mathrm{s}}$ (slow methanol utilization) phenotype, while in other cases sorbitol cofeeding did not have a significant impact or even had a negative effect on specific enzyme productivity (Jungo et al. 2007; Zhu et al. 2011a, b). This inconsistency may be due to strain background (Ramon et al. 2007), gene dosage of foreign proteins (Ramon et al. 2007), or the specific applied feeding strategy (Celik et al. 2009), and the underlying mechanisms remain to be elucidated. It is often overlooked that although mixed feeding increases the metabolic flux towards the synthesis of foreign proteins, it can also cause protein folding stress in the host cells by overwhelming the secretory machinery required for correct folding of the nascent proteins (Yang and Zhang 2018). This can result in a shift of the overall protein expression bottleneck to the secretion pathway. Therefore, to maximize the effect of the mixed feeding, the secretion pathway of yeast cells should also be augmented accordingly.

To test this hypothesis, the individual and synergistic effects of co-feeding of sorbitol or yeast extract and Haclp overexpression on the secretory expression of the model protein glucose oxidase (Gox) as well as cell growth were investigated, both in shake flasks and a laboratory fermenter. The results showed that combining the mixed feeding strategy with secretory pathway engineering can lead to very high increases (threefold) of protein production levels.

\section{Methods}

\section{Plasmids, gene, and reagents}

The gene encoding PpHaclp and $H s \mathrm{Xbp} 1$ (under the Genebank accession number CCA36843.1 and NP_001073007.1, respectively) and Glucose oxidase (Genebank accession number AID16306.1) encoding gene from Aspergillus niger were synthesized by Genewiz (Suzhou, China), with codon optimization for P. pastoris. The plasmid pPICZA and pPICZ $\alpha$ A (Invitrogen, Thermo Fisher Scientific, USA) were used as the starting vectors. RNAprep pure kit, HiScript II QRT Supermix, and the genomic DNA extraction kit were purchased from Tiangen Biotech, and $o$-nitrophenyl $\beta$-D-galactopyranoside (oNPG) was from Sigma-Aldrich, USA. Other chemicals used in this study were of analytical grade and commercially available.

\section{Construction of recombinant plasmids}

PCR fragments encoding the $H s \mathrm{Xbp} 1$ and $P p H a c 1 p$ genes were double digested with EcoRI and NotI and cloned between the corresponding sites of the inducible vector pPICZA to generate the recombinant plasmid, pPICZ$H s \mathrm{Xbp}$ and pPICZ-PpHaclp, respectively. For integration of recombinant protein, a hygromycin-based vector was used. Gene encoding hygromycin gene was cloned from Klebsiella pneumonia and assembled with fragment amplified from pPICZ $\alpha$ using the Gibson assembly cloning kit and transformed into DH5 $\alpha$ to generate recombinant vector pPICH $\alpha$. The PCR fragment coding Gox was transformed into BstBI and NotI site of pPICH $\alpha$ to generate pPICH $\alpha$-Gox. Details of oligonucleotides are given in Additional file 1: Table S1.

\section{Construction of recombinant strains}

pPICH $\alpha-G o x$ was linearized by $\mathrm{Sa1I}$ and transformed with GS115 competent cell by electroporation $(1500 \mathrm{~V}$ charging voltage, $200 \Omega$ resistance, and $50 \mu \mathrm{F}$ capacitance). The successful transformant was selected on $50 \mathrm{mg} / \mathrm{L}$ hygromycin on YPD-based medium. The competent cell of the recombinant strains was thereafter transformed with Sa1I-linearized pPICZ-HsXbp1 and pPICZ-P $p$ Haclp. The positive transformants were selected on $50 \mathrm{mg} / \mathrm{L}$ Zeocin on YPD-based medium and designated as GSgox- $H s$ and GSgox- $P p$, respectively. Information on the plasmids and strains used is listed in Table 1.

\section{Shake flask cultivation}

Three feeding [methanol only, methanol/sorbitol (S) $(5: 1 \mathrm{~g} / \mathrm{g})$, and methanol/yeast extract (YE) $(5: 1 \mathrm{~g} / \mathrm{g})]$ strategies were used to evaluate the fermentation profiles of the recombinant strains producing Gox. The recombinant strains were precultured in YPD (yeast extract $1 \%$, peptone $2 \%$, glucose $2 \%$ ) for $24 \mathrm{~h}$ and transferred into $25 \mathrm{~mL}$ BMMY (per liter: mono-potassium phosphate $8.7 \mathrm{~g}$, YNB $13.4 \mathrm{~g}$, biotin $0.4 \mathrm{mg}$, peptone $20 \mathrm{~g}$, yeast extract $10 \mathrm{~g}, \mathrm{pH}$ 6.0) with initial $\mathrm{OD}_{600}$ of 8 in a $250 \mathrm{~mL}$ flask and incubated at $30{ }^{\circ} \mathrm{C}, 200 \mathrm{rpm}$. The feeding process was started by adding $200 \mu \mathrm{L}$ absolute methanol to each flask, and $200 \mu \mathrm{L}$ methanol was fed at $12 \mathrm{~h}$ interval. Sorbitol and YE co-feeding was the same as the standard procedure except that sorbitol and YE were fed together with methanol (the weight ratio of methanol to sorbitol or YE was 5:1). The cell density at $\mathrm{OD}_{600}$ was determined and samples were kept for further analysis.

\section{Fed-batch cultivation setup}

Fermentations were carried out in a 1-L stirred tank reactor (Infors, Switzerland) with $0.8 \mathrm{~L}$ of BMGY (per liter: potassium phosphate $8.7 \mathrm{~g}$, YNB $13.4 \mathrm{~g}$, biotin 
Table 1 Strains and plasmids used in the study

\begin{tabular}{|c|c|c|}
\hline Plasmids/strains & Descriptions & Reference \\
\hline \multicolumn{3}{|l|}{ Plasmids } \\
\hline $\mathrm{pPICZ}$ & Vector for extracellular expression recombinant vector carrying & Invitrogen \\
\hline pPICZaA & Vector for extracellular expression & Invitrogen \\
\hline $\mathrm{pPICHa}$ & Recombinant vector carrying hygromycin gene from Klebsiella pneumonia & This study \\
\hline pPICZa-HsXbp1 & pPICZaA-based vector carrying Hac1p from H. sapiens; Zeor & This study \\
\hline pPICZa-PpHac1p & pPICZaA-based vector carrying Hac1p from P. pastoris; Zeor & This study \\
\hline pPICHa-Gox & pPICHa-based vector carrying glucose oxidase gene & This study \\
\hline \multicolumn{3}{|l|}{ Strains } \\
\hline E. coli DH5a & Commercial transformation host for cloning & Takara \\
\hline P. pastoris GS115 & $\begin{array}{l}\text { Commercial transformation host for } \\
\text { Cloning; his4 }{ }^{-}, \text {Mut }^{+}\end{array}$ & Invitrogen \\
\hline GSgox & GS115 integrated with inducible glucose oxidase gene & This study \\
\hline GSgox-Hs & GS115-Gox integrated with linearized pPICZaA-HsHac1p & This study \\
\hline GSgox-Pp & GS115-Gox integrated with linearized pPICZaA-PpHac1p & This study \\
\hline
\end{tabular}

$0.4 \mathrm{mg}$, peptone $20 \mathrm{~g}$, yeast extract $10 \mathrm{~g}$, glycerol $10 \mathrm{~g}$; $\mathrm{pH}$ 6.0) to which $4.0 \mathrm{~mL}$ PTM1 trace salts (per liter: $6 \mathrm{~g}$ $\mathrm{CuSO}_{4} \cdot 5 \mathrm{H}_{2} \mathrm{O}, 0.09 \mathrm{~g} \mathrm{KI}, 3 \mathrm{~g} \mathrm{MnSO}_{4} \cdot \mathrm{H} 2 \mathrm{O}, 0.02 \mathrm{~g} \mathrm{H}_{3} \mathrm{BO}_{3}$, $0.2 \mathrm{~g} \mathrm{MoNa}_{2} \mathrm{O}_{4} \cdot 2 \mathrm{H}_{2} \mathrm{O}, 0.5 \mathrm{~g} \mathrm{CoCl}_{2}, 20 \mathrm{~g} \mathrm{ZnCl}_{2}, 65 \mathrm{~g}$ $\mathrm{FeSO}_{4} \cdot 7 \mathrm{H}_{2} \mathrm{O}, 0.2 \mathrm{~g}$ biotin, $5.0 \mathrm{~mL} \mathrm{H} \mathrm{SO}_{4}$ ) were added. The cultivation conditions were: temperature $30{ }^{\circ} \mathrm{C}, \mathrm{pH}$ controlled at 6.0 by adding $\mathrm{NH}_{4} \mathrm{OH}(28 \%$, v/v), dissolved oxygen tension controlled above $20 \%$ with air flow rate at $2 \mathrm{~L} / \mathrm{min}$.

The conventional P. pastoris cultural system was adopted. The entire cultivation started with a batch phase (phase I) lasting for about 20-24 h, followed by a $50 \%$ glycerol feeding phase (phase II) until the biomass concentration reached approximately $\mathrm{OD}_{600} 200$. Phase III involves the one-time addition of $0.25 \% \mathrm{v} / \mathrm{v}$ methanol and allows the cell to adapt to methanol metabolism usually $2 \mathrm{~h}$. The induction phase (phase IV) was carried out by maintaining $5 \mathrm{~g} / \mathrm{L}$ methanol using an online detector and the DO kept in the range of $20-30 \%$. For mixed feeding strategy, methanol was co-fed with sorbitol or YE at a ratio of $5: 1(\mathrm{~g} / \mathrm{g})$.

\section{Measurement of glucose oxidase activity}

Gox activity was measured by mixing $2.5 \mathrm{~mL}$ of $o$-dianisidine solution, $0.3 \mathrm{~mL}$ of $18 \% \beta$-D-glucose, and $0.1 \mathrm{~mL}$ of $90 \mathrm{U} / \mathrm{mL}$ Horseradish peroxidase, and incubate at $35{ }^{\circ} \mathrm{C}$ for $2 \mathrm{~min}$. $0.1 \mathrm{~mL}$ of fermented sample was thereafter added to the tube and allowed to react for $3 \mathrm{~min}$. $2 \mathrm{~mL}$ of $2 \mathrm{M} \mathrm{H}_{2} \mathrm{SO}_{4}$ was then used to stop the reaction and the absorbance was determined at $540 \mathrm{~nm}$. One unit of enzyme formed is equal to oxidizing $1.0 \mu \mathrm{mol} / \mathrm{min}$ of $\beta$-D-glucose to D-glucon- $\delta$-lactone and $\mathrm{H}_{2} \mathrm{O}_{2}$. Gox activity per biomass was calculated by dividing the enzyme activity by the corresponding $\mathrm{OD}_{600}$ values.

\section{RNA preparation}

The total RNA was extracted following the protocol enclosed in RNA prep pure kit (Tiangen Biotech, Beijing, China). The mRNA was subjected to reverse transcription to obtain single-stranded cDNA following the manufacturer's guide.

\section{Real-time qPCR and copy number determination}

Each $20 \mu \mathrm{L}$ reaction contained $10 \mu \mathrm{L} 2 \times$ SYBR Premix Ex $\mathrm{Taq}^{\mathrm{TM}}, 0.4 \mu \mathrm{L} 50 \mu \mathrm{M}$ forward and reverse primers, $2.0 \mu \mathrm{L}$ cDNA sample, and 7.2 $\mu \mathrm{L}$ nuclease-free water. All realtime $\mathrm{qPCR}$ reactions were run in triplicate on a Light Cycler ${ }^{\circledR} 96$ (Roche, Switzerland) using the following program: $95{ }^{\circ} \mathrm{C}$ for $3 \mathrm{~min}, 45$ cycles of $95{ }^{\circ} \mathrm{C}$ for $5 \mathrm{~s}$, and $60{ }^{\circ} \mathrm{C}$ for $20 \mathrm{~s}$. The specificity of amplicons was verified by melting curve analysis after 40 cycles and agarose gel electrophoresis. The $2^{-\Delta \Delta}$ method was used to determine the expression level of Gox with $A C T$ gene as endogenous control.

\section{Results}

\section{Construction of recombinant strains and Gox expression}

The gox gene derived from Aspergillus niger was codon optimized for $P$. pastoris, chemically synthesized and cloned into the pPICH $\alpha$ vector. The resulting recombinant vector pPICH $\alpha$-gox was linearized and introduced into P. pastoris GS115, yielding the yeast strain GSgox. GSgox was fermented in shake flasks and induced for $72 \mathrm{~h}$ with methanol feeding at $12 \mathrm{~h}$ intervals. The enzyme activity reached $24.6 \mathrm{U} / \mathrm{mL}$ at the end of the batch fermentation. SDS-PAGE showed a clearly visible band corresponding to a protein of approx. $80 \mathrm{kDa}$ (Fig. 1c). The band indicated a larger protein than the theoretical size $(63.5 \mathrm{kDa})$, which was expected due to glycosylation of Gox (Fig. 1). 

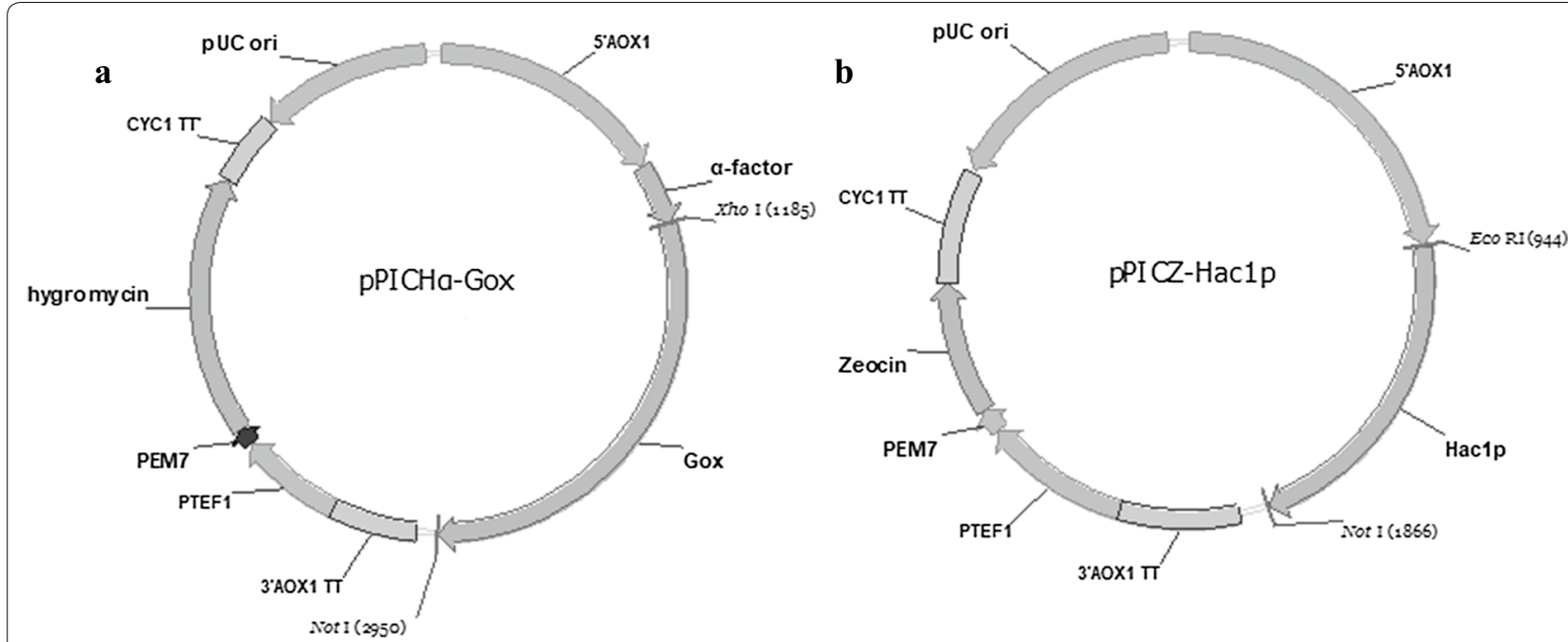

c

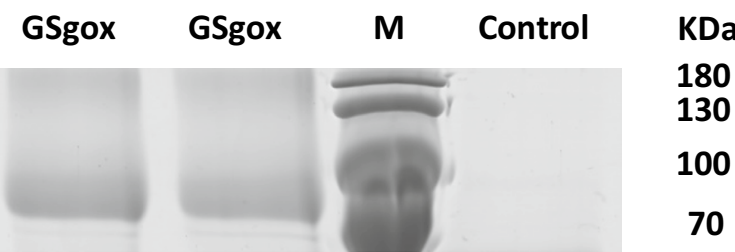

Fig. 1 Construction of recombinant strains and Gox expression. a The expression vector containing Gox (from Aspergillus niger). b The expression vector containing Hac1p (from P. pastoris and H. sapiens). c Gox expression analysis by SDS-PAGE

\section{Effect of mixed feeding strategies on Gox expression}

Co-feeding of either sorbitol or YE with methanol was tested with a pure methanol-feeding strategy as the control. The results showed that both sorbitol and YE co-feeding significantly increased the cell growth (by 16.0 and $45.0 \%$, respectively) compared with the control (Fig. 2a). However, only YE increased the Gox expression level (by 59.4\%), while sorbitol co-feeding even led to a decrease of the enzyme yield (by 17.0\%) (Fig. 2b). The Gox secretion capabilities of GSgox under different conditions were also estimated by normalizing the enzyme levels to the $\mathrm{OD}_{600}$ values. The results showed that sorbitol co-feeding decreased the Gox activity per biomass by $28.4 \%$ and YE increased the value by $10.0 \%$. Furthermore, transcription analysis showed that the mRNA level of GSgox with sorbitol was only $38.8 \%$ of that of the control (Additional file 1: Figure S1). Consequently, only YE cofeeding was used in further experiments.

\section{Effects of Hac1p homologue co-expression on Gox expression}

The secretion pathway of recombinant $P$. pastoris was engineered by individually overexpressing two Haclp gene homologues (PpHac1p and HsXbp1) in GSgox, respectively. The resulting strains GSgox-Pp and GSgox$H s$ showed 34.1 and $25.3 \%$ increase of Gox expression at $48 \mathrm{~h}$, respectively, but only GSgox- $P p$ showed an increase of the Gox level at $72 \mathrm{~h}$, amounting to only $7.0 \%$ (Fig. 3). When the enzyme activity per biomass was considered, PpHac1p overexpression showed a $16.4 \%$ increase in specific Gox levels, while $H s \mathrm{Xbp} 1$ led to $13.7 \%$ decrease compared with the control.

\section{Effects of YE co-feeding combined with Hac1p gene overexpression on Gox expression}

YE co-feeding strategies were applied to GSgox-Pp and GSgox- $H s$ with GSgox as a control. The results showed that YE co-feeding did not lead to difference in the cell growth among the three strains but caused a remarkable increase of Gox expression in GSgox-Pp and GSgox- $H s$ (73.6 and 19.3\% increase, respectively) (Fig. 4). The Gox level of GSgox- $P p$ reached $68.1 \mathrm{U} / \mathrm{mL}$, which was 2.8fold higher than the starting value. In terms of enzyme activity per biomass, the individual application of YE cofeeding and Hac1p overexpression strategies resulted in only 10.0 and $16.4 \%$ increases of Gox secretion over the starting value, while combining the two strategies had a synergistic effect, leading to an increase of $89.2 \%$. 

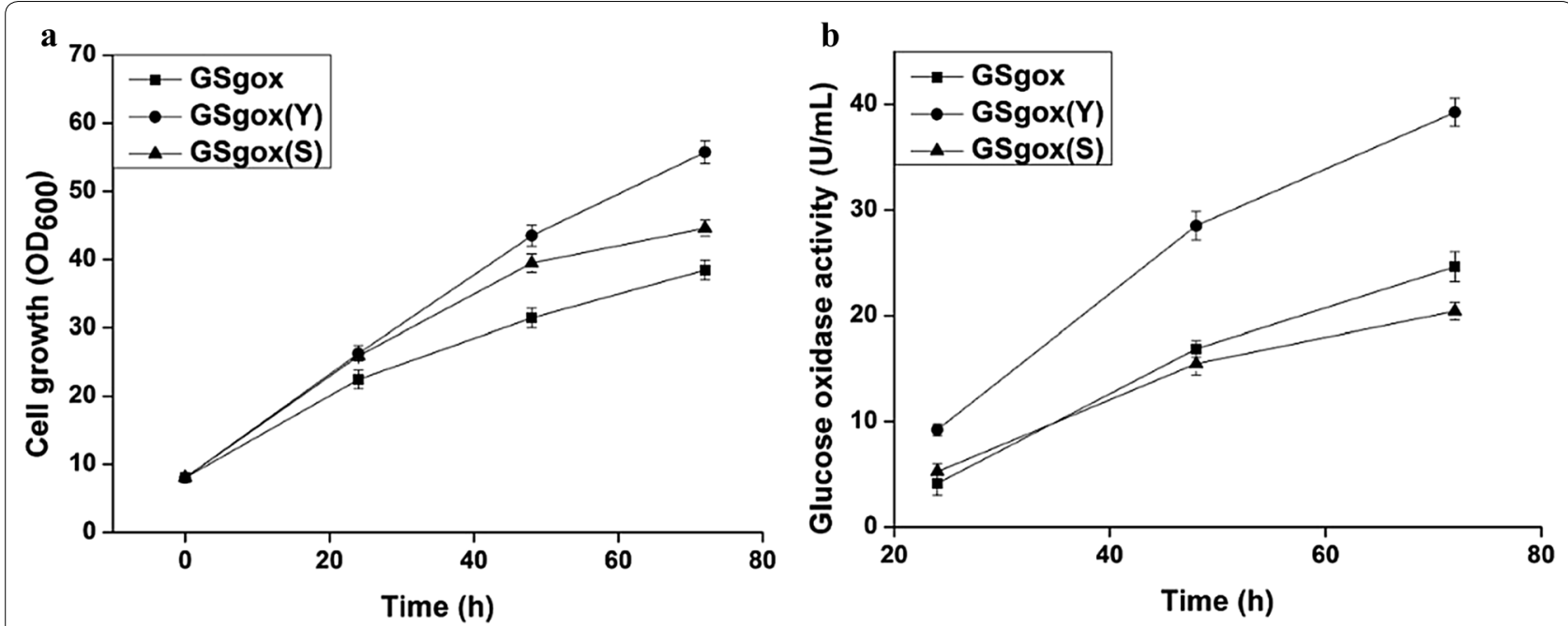

Fig. 2 Effects of co-feeding strategies on Gox expression. a Cell growth profile. b Gox activity profile. (Y) Co-feeding with yeast extract. (S) Co-feeding with sorbitol. Sole methanol feeding (square), methanol/yeast extract (circle), and methanol/sorbitol (triangle). Three parallel flasks are tested for each strain at $30^{\circ} \mathrm{C}$. Error bars represent deviations $(n=3)$
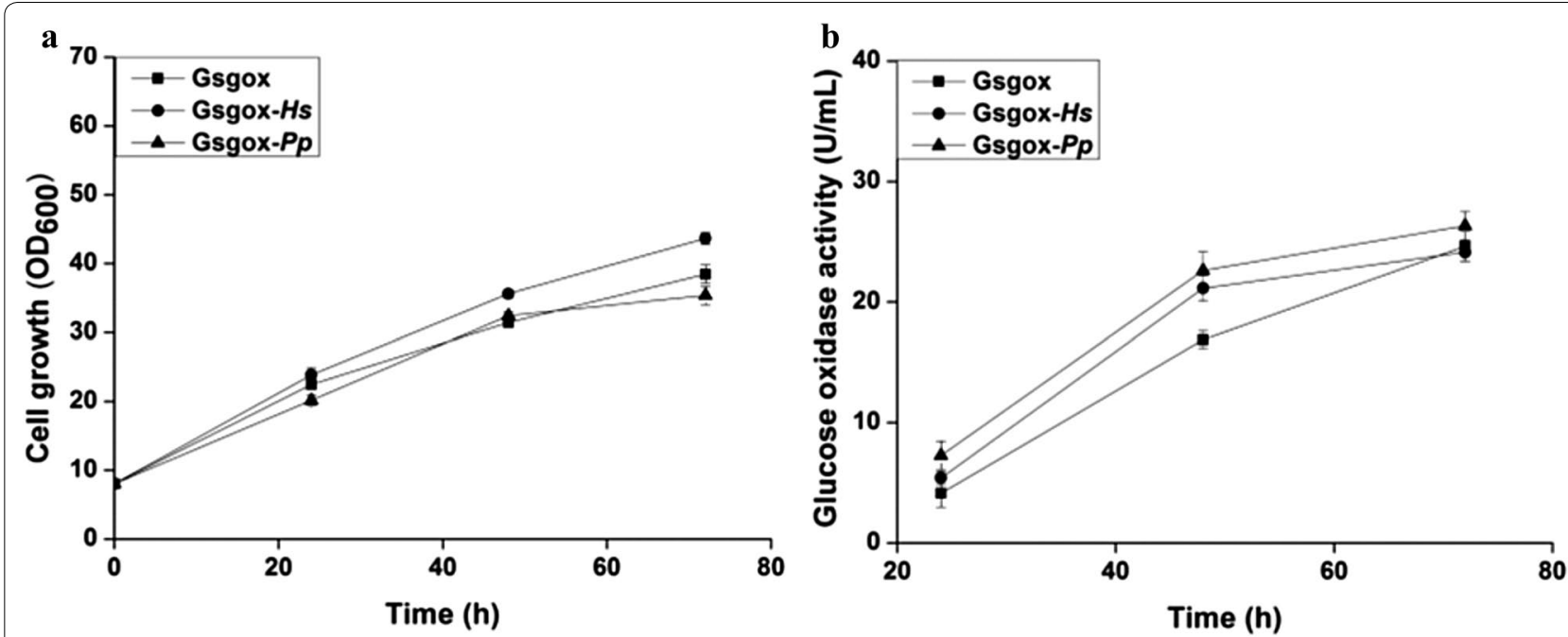

Fig. 3 Effects of Hac1p homologue co-expression on Gox expression. a Cell growth profile. b Gox activity profile. GSgox (square), GSgox-Hs, (GSgox


Error bars represent deviations $(n=3)$

\section{The effects of the combined strategy on strain} performance in a fermenter

The combined strategies were also applied in a 1-L fermenter. With methanol induction only, the volumetric activity of GSgox after $96 \mathrm{~h}$ of induction was $264.3 \mathrm{U} /$ $\mathrm{mL}$ Gox (Fig. 5). YE co-feeding increased the activity to $584.3 \mathrm{U} / \mathrm{mL}$. When the same strategy was applied to GSgox- $P p$, the activity was further increased to $787.4 \mathrm{U} /$ $\mathrm{mL}$, which was $297 \%$ higher than the starting titer.

\section{Discussion}

Mixed feeding strategies combining methanol with complex carbon sources have been applied in the P. pastoris system to increase the cell growth and protein production since 1990 (Brierley et al. 1990). Such strategies were first applied to $\mathrm{Mut}^{\mathrm{S}}$ P. pastoris strains, which can only metabolize methanol very slowly and, therefore, need extra energy for biomass accumulation and expression of foreign proteins. Later, the advantages of mixed feeding were also shown in $\mathrm{Mut}^{+}$P. pastoris strains (Sreekrishna et al. 1997). This is especially true for strains with high 

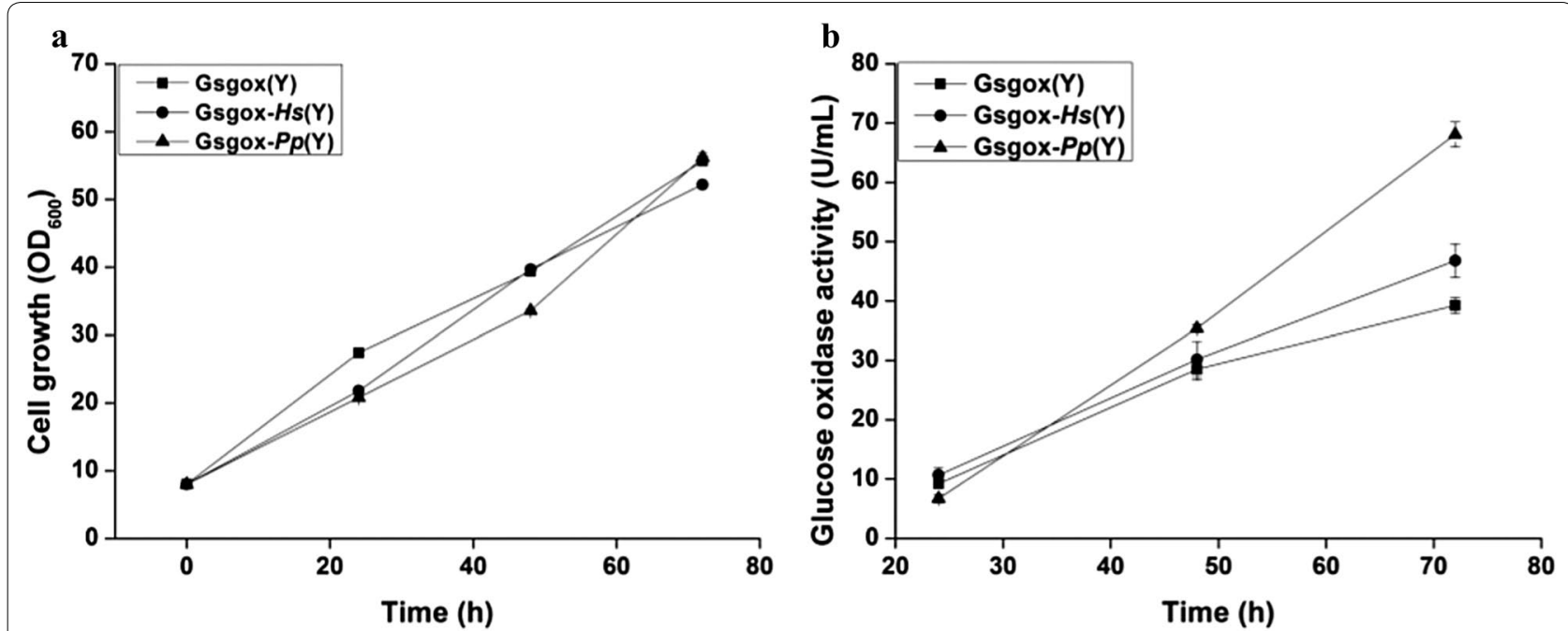

Fig. 4 Synergistic effect of Hac1p and YE co-feeding on Gox production. a Cell growth profile. b Gox activity profile. (Y) Co-feeding with yeast extract, (S) Co-feeding with sorbitol. GSgox co-fed with yeast extract (square), GSgox-Hs co-fed with yeast extract (circle) and GSgox-Pp co-fed with yeast extract (triangle). Three parallel flasks are tested for each strain at $30^{\circ} \mathrm{C}$. Error bars represent deviations $(n=3)$
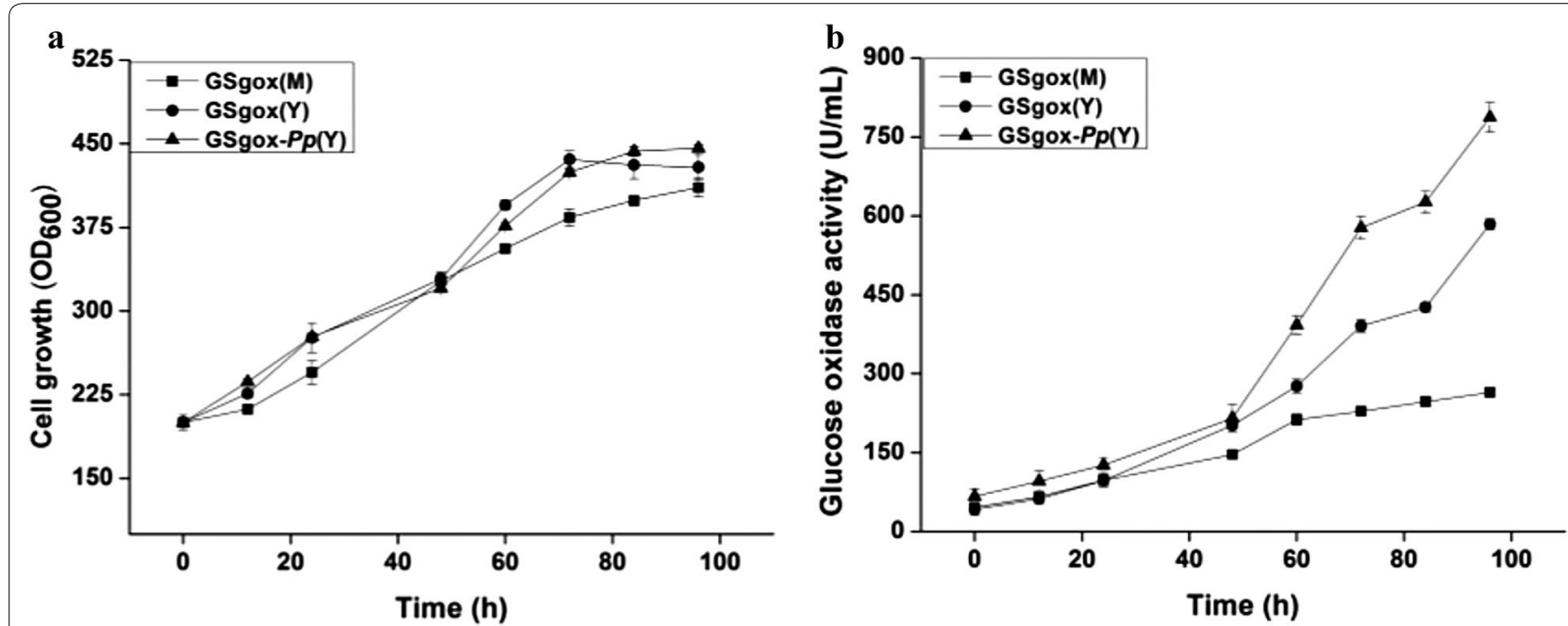

Fig. 5 Synergistic effect of Hac1 $\mathrm{p}$ and YE co-feeding on Gox production in a 1-L fermenter. a Cell growth. b Glucose oxidase activity. GSgox with sole methanol feeding (square), GSgox co-fed with yeast extract (circle), GSgox-Pp co-fed with yeast extract (triangle)

copy numbers of heterologous expression cassettes, whose methanol utilization rates were often compromised due to downregulation of AOX1 (Camara et al. 2017; Zhu et al. 2011a, b).

Nevertheless, co-feeding in some cases did not increase and even decreased the protein expression capacity of yeast cells (Jungo et al. 2007; Zhu et al. 2011a, b), which limited the effects of mixed feeding strategy. We hypothesized that this phenomenon is due to increased protein synthetic flux, causing folding stress that leads to a bottleneck in the protein secretion pathway. Therefore, engineering the secretion pathway is necessary to maximize the effects of co-feeding strategies.

This hypothesis was investigated by adopting the individual and synergistic effects of co-feeding of sorbitol or YE with methanol and concomitant overexpression of Haclp gene homologues on the secretory expression of the model protein Gox. Sorbitol is regarded as a nonrepressive carbon source with respect to the AOX1 promoter (Thorpe et al. 1999; Xie et al. 2005), and it remains one of the most commonly used ancillary carbon sources for co-feeding fermentations. However, our previous 
research suggested that sorbitol may repress the transcription of foreign genes at least in some circumstances (Zhu et al. 2013). This was also observed in this work, with both reduced enzyme activity per biomass and GOX transcription in the presence of sorbitol. By contrast, YE was superior to sorbitol in terms of stimulating both protein synthesis and cell growth due to its non-repression to AOX1 promoter and rich carbon precursors and energy it supplied (Zhu et al. 2013), and therefore can serve as an important carbon source for the mixed feeding strategy.

Overexpression of the Haclp gene is one of the most widely used strategies to augment the secretion pathway of eukaryotic expression systems (Idiris et al. 2010). In addition to yeast Hac1p, its homologues from higher eukaryotes can also improve the secretion of heterologous proteins in P. pastoris (Bankefa OE, submitted for publication). However, using only the Hac1p overexpression strategies resulted in limited success in this work, whereby the $P p H a c 1 p$-overexpressing strain only showed a $16.4 \%$ increase of Gox levels, and the Gox level of GSgox- $H s$ was even slightly decreased compared with the control. By contrast, after co-feeding YE, the Gox expression levels of GSgox-P $p$ and GSgox- $H s$ increased by 73.6 and $19.3 \%$, which illustrated that protein synthesis rather than secretion is the main bottleneck for protein expression without co-feeding GSgox strain.

Individual usage of co-feeding of YE resulted in 1.6and 2.2-fold increases of GOX production in the GSgox strain in shake flask and fermenter culture, respectively. When the secretion pathway of GSgox was engineered by overexpressing of $P p \mathrm{Hac1p}$, the Gox levels were further increased to $68.1 \mathrm{U} / \mathrm{mL}$ (shake flask) and 787.4 U/ $\mathrm{mL}$ (fermenter), representing 2.8- and 3.0-fold increases compared with the control, respectively. These results indicated that after YE co-feeding, the secretion pathway likely became the main limiting factor for Gox expression.

\section{Conclusions}

Although mixed feeding strategies have been widely used to develop processes for P. pastoris, it should be kept in mind that co-feeding of alternative carbon sources may also result in folding stress to the host cells, which can effectively shift the protein expression bottleneck to the secretion step. Consequently, a combined strategy encompassing both co-feeding and secretion pathway engineering can provide a better balance of protein synthesis and secretion, providing an effective strategy to improve foreign protein secretion in eukaryotic systems.

\section{Additional file}

Additional file 1: Table S1. The oligonucleotides used in this study. Figure S1. Relative transcription levels of Gox with different co-feeding strategies. Control: GSgox cultured on methanol; YE: Gsgox cultured on mixed methanol and yeast extract (5:1 g/g); Sorbitol: Gsgox cultured on mixed methanol and sorbitol (5:1 g/g).

\section{Authors' contributions}

TZ and YL designed the experiments; OEB and MY collected the data; OEB, $T Z$, and $Y L$ analyzed the data. OEB, $T Z$, and $Y L$ wrote the paper. All the authors reviewed the manuscript. All authors read and approved the final manuscript.

\section{Author details}

${ }^{1}$ CAS Key Laboratory of Microbial Physiological and Metabolic Engineering, State Key Laboratory of Microbial Resources, Institute of Microbiology, Chinese Academy of Sciences, No. 1 West Beichen Road, Chaoyang District, Beijing 100101, China. ${ }^{2}$ University of Chinese Academy of Sciences, Beijing 100190, China.

\section{Acknowledgements}

We acknowledged the support of the Centre of excellence for Biotechnology and the Institute of Microbiology Chinese Academy of Science Beijing. P.R

China.

\section{Competing interests}

The authors declare that they have no competing interests.

Availability of data materials

The datasets supporting the conclusions of this article are included in the main manuscript.

\section{Consent for publication}

The authors approved the consent for publishing the manuscript.

\section{Ethics approval and concept to participate}

All the authors have read and agreed the ethics for publishing the manuscript.

\section{Funding}

This work was supported by the Key International Cooperation Project of the Chinese Academy of Sciences (155112KYSB20160010) and the CAS-TWAS

President's Fellowship Program 2014/2018.

\section{Publisher's Note}

Springer Nature remains neutral with regard to jurisdictional claims in published maps and institutional affiliations.

Received: 12 April 2018 Accepted: 22 May 2018

Published online: 26 May 2018

\section{References \\ Brierley RA, Bussineau C, Kosson R, Melton A, Siegel RS (1990) Fermentation development of recombinant Pichia pastoris expressing the heterologous gene: bovine lysozyme. Ann NY Acad Sci 589:350-362 \\ Camara E, Landes N, Albiol J, Gasser B, Mattanovich D, Ferrer P (2017) Increased dosage of AOX1 promoter-regulated expression cassettes leads to tran- scription attenuation of the methanol metabolism in Pichia pastoris. Sci Rep 7:44302. https://doi.org/10.1038/srep44302 \\ Celik E, Calik P, Oliver SG (2009) Fed-batch methanol feeding strategy for recombinant protein production by Pichia pastoris in the presence of co- substrate sorbitol. Yeast 26:473-484. https://doi.org/10.1002/yea.1679}


Cos O, Ramon R, Montesinos JL, Valero F (2006) Operational strategies, monitoring and control of heterologous protein production in the methylotrophic yeast Pichia pastoris under different promoters: a review. Microb Cell Fact 5:17. https://doi.org/10.1186/1475-2859-5-17

Gu L, Zhang J, Liu B, Du G, Chen J (2015) High-level extracellular production of glucose oxidase by recombinant Pichia pastoris using a combined strategy. Appl Biochem Biotechnol 175:1429-1447. https://doi.org/10.1007/ s12010-014-1387-z

Idiris A, Tohda H, Kumagai H, Takegawa K (2010) Engineering of protein secretion in yeast: strategies and impact on protein production. Appl Microbiol Biotechnol 86:403-417. https://doi.org/10.1007/s00253-010-2447-0

Jungo C, Schenk J, Pasquier M, Marison IW, von Stockar U (2007) A quantitative analysis of the benefits of mixed feeds of sorbitol and methanol for the production of recombinant avidin with Pichia pastoris. J Biotechnol 131:57-66. https://doi.org/10.1016/j.jbiotec.2007.05.019

Looser V, Bruhlmann B, Bumbak F, Stenger C, Costa M, Camattari A, Fotiadis D, Kovar K (2015) Cultivation strategies to enhance productivity of Pichia pastoris: a review. Biotechnol Adv 33:1177-1193. https://doi. org/10.1016/j.biotechadv.2015.05.008

Ramon R, Ferrer P, Valero F (2007) Sorbitol co-feeding reduces metabolic burden caused by the overexpression of a Rhizopus oryzae lipase in Pichia pastoris. J Biotechnol 130:39-46. https://doi.org/10.1016/j.jbiot ec.2007.02.025

Sreekrishna K, Brankamp RG, Kropp KE, Blankenship DT, Tsay JT, Smith PL, Wierschke JD, Subramaniam A, Birkenberger LA (1997) Strategies for optimal synthesis and secretion of heterologous proteins in the methylotrophic yeast Pichia pastoris. Gene 190:55-62

Thorpe ED, D'Anjou MC, Daugulis AJ (1999) Sorbitol as a non-repressing carbon source for fed-batch fermentation of recombinant Pichia pastoris. Biotechnol Lett 21:669-672. https://doi.org/10.1023/A:1005585407601

Xie J, Zhou Q, Du P, Gan R, Ye Q (2005) Use of different carbon sources in cultivation of recombinant Pichia pastoris for angiostatin production. Enzyme Microb Technol 36:210-216

Yang Z, Zhang Z (2018) Engineering strategies for enhanced production of protein and bio-products in Pichia pastoris: a review. Biotechnol Adv 36:182-195. https://doi.org/10.1016/j.biotechadv.2017.11.002

Zhu T, Guo M, Zhuang Y, Chu J, Zhang S (2011a) Understanding the effect of foreign gene dosage on the physiology of Pichia pastoris by transcriptional analysis of key genes. Appl Microbiol Biotechnol 89:1127-1135. https://doi.org/10.1007/s00253-010-2944-1

Zhu T, You L, Gong F, Xie M, Xue Y, Li Y, Ma Y (2011 b) Combinatorial strategy of sorbitol feeding and low-temperature induction leads to high-level production of alkaline $\beta$-mannanase in Pichia pastoris. Enzyme Microb Technol 49:407-412. https://doi.org/10.1016/j.enzmictec.2011.06.022

Zhu T, Hang H, Chu J, Zhuang Y, Zhang S, Guo M (2013) Transcriptional investigation of the effect of mixed feeding to identify the main cellular stresses on recombinant Pichia pastoris. J Ind Microbiol Biotechnol 40:183-189. https://doi.org/10.1007/s10295-012-1225-7

\section{Submit your manuscript to a SpringerOpen ${ }^{\odot}$ journal and benefit from:}

- Convenient online submission

- Rigorous peer review

- Open access: articles freely available online

- High visibility within the field

- Retaining the copyright to your article

Submit your next manuscript at $\boldsymbol{\nabla}$ springeropen.com 